\title{
Flavonoid Contents and Antioxidant Activity in Fruit, Vegetables and Other Types of Food
}

\author{
Juliana Cristina Pereira Calado ${ }^{1}$, Paula Adriana Albertão ${ }^{1}$, Erica Aparecida de Oliveira1, \\ Mario Henrique Sisto Letra ${ }^{1}$, Alexandra Christine Helena Frankland Sawaya ${ }^{2}$, \\ Maria Cristina Marcucci ${ }^{*}$ \\ ${ }^{1}$ Post-Graduated School in Pharmacy, Anhanguera University of São Paulo (UNIAN-SP), São Paulo, Brazil \\ ${ }^{2}$ Department of Plant Biology and Pharmacy Course, Institute of Biology, Universidade Estadual de Campinas, \\ UNICAMP, Campinas, Brazil \\ Email: ${ }^{*}$ Cris.marcucci@yahoo.com.br
}

Received 20 March 2015; accepted 9 April 2015; published 15 April 2015

Copyright (C) 2015 by authors and Scientific Research Publishing Inc.

This work is licensed under the Creative Commons Attribution International License (CC BY). http://creativecommons.org/licenses/by/4.0/

(c) (i) Open Access

\section{Abstract}

Flavonoids are a class of natural polyphenolic compounds which cannot be synthesized by humans. These substances possess a series of biological properties, acting on biological systems as antioxidants. The purpose of this study was to analyze the properties of certain foods, determining the total flavonoids as well as their antioxidant activity and fat concentration. We evaluated several foods purchased at the local market, with respect to its antioxidant activity, using two experimental models, the discoloration of DPPH' radical and ABTS-. Some foods such as pitanga showed antioxidant activity. The lipid content of fatty foods like açaí, cacao and cupuaçú was determined. Other foods, including pitanga, açaí, cacao and cupuaçú, were evaluated for flavonoid content and antioxidant activity using multivariate statistical analysis (PCA) as a statistical tool to evaluate the correlation between these two parameters. As samples with $\mathrm{ED}_{50}$ up to $500 \mu \mathrm{g} / \mathrm{mL}$ show promising antioxidant activity, several Brazilian fruit and vegetables could be consumed to this end, with a good correlation between flavonoid content and antioxidant activity in most samples. The daily dose of different types of food for antioxidant activity has been calculated based on these results.

\section{Keywords}

Amount of Lipids, Antioxidant Activity, Chemometric Analysis, Fat Content, Flavonoids, Food, Fruit, Vegetables

\footnotetext{
${ }^{*}$ Corresponding author.
}

How to cite this paper: Calado, J.C.P., Albertão, P.A., de Oliveira, E.A., Letra, M.H.S., Sawaya, A.C.H.F. and Marcucci, M.C. (2015) Flavonoid Contents and Antioxidant Activity in Fruit, Vegetables and Other Types of Food. Agricultural Sciences, 6, 426-435. http://dx.doi.org/10.4236/as.2015.64042 


\section{Introduction}

The consumption of nutrients and other biologically active compounds help their consumers lead healthier lives. The antioxidant activity of some foods reduces the risk of certain diseases, as free radicals may affect many biological molecules including lipids, proteins, carbohydrates, and vitamins present in food [1].

The low incidence of disease in some countries called attention to their population's diet. For example, Eskimos have a sea-food based diet (which is rich in omega 3 and 6 lipids) and a low incidence of heart problems. The same tendency is observed in the French who consume red wine, as well as the Oriental populations who consume soybean and have reduced incidence of breast cancer. It has been confirmed that the habit of consuming fruit, vegetables, and certain types of foods help reduce the risk of coronary disease and cancer [2].

Phenolic compounds are commonly found in vegetable based food, and are important components of human diet. They have diverse properties such as antioxidant, anti-aging, anti-cancer, anti-inflammatory activity [3]. Phenolic compounds have been used as antioxidants and mainly inhibit free radicals and block their chain reactions [4].

Free radicals may be related to a series of illnesses, causing tissue damage, arteriosclerosis, rheumatic arthritis, aging, circulatory diseases, neurodegenerative diseases, alteration of DNA, causing different types of cancer and hundreds of other pathologies [5]. Due to the mass production of free radicals during metabolic processes, many innate processes exist to counteract the damage caused by those free radicals; such as those formed by the loss, or addition, of a single electron to a non-radical molecule. The levels of these free radicals fluctuate during various conditions, such as higher oxygenation of the tissues, accumulation of lactic acid (lactoacidosis) and ketones (ketoacidose). Our own bodies generally combat these radicals endogenously. However, when the radical levels rise to high levels or go up too quickly (possibly due to external agents) our bodies are overburdened and this is where food with antioxidant properties enters the scene and helps combat the excess of free radicals [6]-[8]. So, whenever free radicals increase or endogenous antioxidants decrease, oxidative stress ensues, resulting in tissue damage. This process generally leads to direct or indirect inflammatory response which consequently further raises the level of free radicals, maintaining tissue damage. Antioxidants taken in from diet play an important role in the preventions of illness, and there is a direct link between oxidative stress and diet which is important for the antioxidant defense of the organism [9].

Flavonoids are an important class of plant pigments, naturally found in fruit and vegetables. This class of naturally occurring polyphenolic compounds which cannot be synthesized by humans possesses a series of biological properties, acting on biological systems as antioxidants. Flavonoids act as antiviral, anti-inflammatory, and antitumoral agents, affecting capillary permeability and acting as exogenous antioxidants. Flavonoids capture and neutralize the oxidative agents, and quench free radicals, inhibiting several enzymes (ciclo-oxigenase, lipooxigenase, NADPH-oxidase, xantine-oxidase, fosfolipase) and stimulating enzymes with antioxidant activity (such as catalase and superoxide dismutase). Therefore flavonoids interfere directly in the formation and propagation of free radicals [4] [7].

Flavonoids present in the diet are directly linked to the prevention of arthrosclerosis, as various studies show that the reduction of total blood cholesterol levels and the antioxidant effect lead to lower risks of arthrosclerosis, teratogenicity, and coronary disease [10].

It has been reported that green vegetables are the source of polyphenolic compounds [10] [11]; so their antioxidant [12] and antimutagenic capacity [13]-[15], effects on apoptosis [16], and antiproliferative mechanisms [17] [18] are related to the presence of these compounds in fruit and vegetables [4].

The objective of this study was to analyze the antioxidant properties of certain foods, determining the total flavonoids as well as their antioxidant activity and fat concentration order to evaluate which types of food can help keep a healthy diet.

\section{Materials and Methods}

\subsection{Plant Material}

All foods were purchased at the local market.

\subsection{Sample Preparation}

All samples were prepared as described in Table 1. 
Table 1. Conditions of food pre-treatment.

\begin{tabular}{|c|c|c|}
\hline Food & Quantity sample (g)/solvent (mL) & Experimental conditions \\
\hline Açaí (Euterpe oleracea mart.) & Without extraction & $\begin{array}{c}\text { Fruit pulp (Control, Açc) } \\
\text { Pulp in oven at } 50^{\circ} \mathrm{C}, 24 \mathrm{~h} \text { (Açe) } \\
\text { Pulp } 60 \text { min, } 100^{\circ} \mathrm{C} \text { (Açf) } \\
\text { Pulp left open in a refrigerator for } 25 \text { days, (Açg) } \\
\text { Pulp }+\mathrm{H}_{2} \mathrm{O}_{2} 10 \text { vol, } 20 \mathrm{~mL} \text { (Açp1) } \\
\text { Pulp }+\mathrm{H}_{2} \mathrm{O}_{2} 10 \text { vol, } 1 \mathrm{~mL} \text { (Açp2) }\end{array}$ \\
\hline Broccolis (Brassica oleracea) raw & $13 / 100^{w}$ & Turbo-extracted, 3 min. Filtered \\
\hline Broccolis cooked & $21 / 100^{w}$ & Boiled, $90 \mathrm{~min}, 150^{\circ} \mathrm{C}$. Filtered \\
\hline $\begin{array}{l}\text { Chocolate-Milk } \\
\text { Chocolate-Bitter } \\
\text { Chocolate-White } \\
\text { Chocolate-Diet }\end{array}$ & $\begin{array}{l}11 / 150^{w} \\
7 / 150^{w} \\
9 / 150^{w} \\
6 / 150^{w}\end{array}$ & $\begin{array}{l}\text { Separately extracted in Soxhlet } 4 \text { hours, } \\
\text { allowed to cool and filtered to remove } \\
\text { the nonpolar fraction. }\end{array}$ \\
\hline Eggplant (Solanum melongena) raw peel & $10 / 100^{\mathrm{w}}$ & Turbo-extracted, 2 min. Filtered \\
\hline Eggplant raw pulp & $10 / 100^{\mathrm{w}}$ & Turbo-extracted, 2 min. Filtered \\
\hline Eggplant cooked peel & $10 / 100^{\mathrm{w}}$ & Boiled $180 \mathrm{~min}, 100^{\circ} \mathrm{C}$. Filtered \\
\hline Eggplant cooked pulp & $10 / 100^{\mathrm{w}}$ & Boiled, $180 \mathrm{~min}, 100^{\circ} \mathrm{C}$. Filtered \\
\hline Kale (Brassica oleracea var. acephala) raw & $31 / 100^{w}$ & Turbo-extracted, 2 min. Filtered \\
\hline Oregano (Origanum vulgare) & $15 / 200^{\mathrm{w}}$ & Turbo-extracted, 2 min. Filtered \\
\hline Parsley (Petroselinum crispum) & $15 / 150^{\mathrm{w}}$ & Turbo-extracted, 2 min, Filtered \\
\hline $\begin{array}{l}\text { Pitanga (Eugenia uniflora) } \\
\text { green } \\
\text { mature } \\
\text { leaves } \\
\text { seeds } \\
\quad \text { inductrialized pulp }\end{array}$ & Without extraction & $\begin{array}{l}\text { Turbo-extracted, lyophilized } 24 \text { - } 48 \mathrm{~h} \text {. } \\
\text { resuspended in water }(1 \mathrm{mg} / \mathrm{mL})\end{array}$ \\
\hline $\begin{array}{l}\text { Squash (Curcubita maxima) raw } \\
\text { Squash (cooked) }\end{array}$ & $\begin{array}{l}30 / 100^{w} \\
20 / 100^{w}\end{array}$ & $\begin{array}{l}\text { Turbo-extracted } 5 \text { min. Filtered } \\
\text { Boiled } 120 \mathrm{~min}, 150^{\circ} \mathrm{C} \text {. Filtered }\end{array}$ \\
\hline Soya (Glycine max) & $20 / 200^{w}$ & $\begin{array}{l}\text { Boiled } 180 \mathrm{~min} \text { at } 200^{\circ} \mathrm{C} \text { and } 45 \mathrm{~min} \text {, } \\
\text { at } 300^{\circ} \mathrm{C} \text {. Filtered }\end{array}$ \\
\hline Tomato raw (Solanum lycopersicum) & $0 / 150^{\mathrm{w}}$ & Turbo-extracted, 2 min. Filtered \\
\hline Tomato cooked & $40 / 100^{w}$ & Boiled $60 \mathrm{~min}, 150^{\circ} \mathrm{C}$. Filtered \\
\hline Walnuts (Carya illinoensis) & 0/100 Hexane & $\begin{array}{l}\text { Reflux at } 100^{\circ} \mathrm{C}, 6 \text { hours. Apolar moiety and residue } \\
\text { separated. Residue extracted with ethanol. Filtered. }\end{array}$ \\
\hline
\end{tabular}

Legend: W, water.

The percentage of soluble solids was obtained (\% $\mathrm{m} / \mathrm{V})$, the flavonoid content and antioxidant activity was determined for all samples. For the pitanga samples (Pi), only the antioxidant activity was determined. The fat contents and antioxidant activity was determined for the samples of cacao, cupuaçú, and açaí.

\subsection{Antioxidant Activity}

\subsubsection{DPPH Method}

Solutions of the fluid extracts $0.01 \%(\mathrm{~m} / \mathrm{V})$ were prepared, adding ethanol to each of the test tubes to obtain the desired dilution. The volume of DPPH` (diphenyl picryl hydrazyl radical, Sigma, USA, $60 \mu \mathrm{M}$ ) was added to the first tube and at 1-minute intervals to all the other tubes. The absorbance at $517 \mathrm{~nm}$ was read after $30 \mathrm{mi}-$ nutes in the first tube and at 1-minute intervals for all the other tubes in a spectrophotometer Cary-50 with probe (Varian, USA). The percent of absorbance versus concentration of extract were plotted on a graph and the $\mathrm{ED}_{50}$ 
was calculated by the minimal squares method [19]. All food samples were tested, except for treatments of açaí because the sample color was similar to DPPH', and both absorbed at the same wavelength.

\subsubsection{ABTS- Method}

The samples were prepared in the same way as for $\mathrm{DPPH}^{*}$ and analyzed as described by Pellegrini et al. [20]. Water and ethanol extracts of cacao (Theobroma cacao L.) (fruit, Ccf e pulp, Ccp), cupuaçu (Theobromagrandiflorum) (fruit, Cpf e pulp, Cpp), açaí (Table 1: Açc, Açe, Açf, Açg, Açp1 e Açp2) and pitanga (Eugenia uniflora) (Piv, Pim, Pif, Pis e Pip) were analyzed in a spectrophotometer Cary-50 with probe (Varian, USA).

\subsection{Lipid Content}

The method described by Bligh and Dyer [21] was used. Ground raw samples of cacao (fruit, Ccf e pulp, Ccp), cupuaçu (fruit, Cpf and pulp, Cpp) e açaí (Table 1: Açc, Açe, Açf, Açg, Açp1 e Açp2) were analyzed; their lipid contents were extracted and weighed (Ohaus, Analytical Plus $0.00000 \mathrm{~g}$ (USA)).

\subsection{Flavonoid Content}

The determination of total flavonoids was effected using a solution of $100 \mu \mathrm{L}$ of each sample with a known percentage of soluble solids, in a $10 \mathrm{~mL}$ flask, completing the volume with methanol (Merck, Germany, stock solution). All dilutions were prepared in triplicate, parting from this stock solution. An aliquot of $200 \mu \mathrm{L}$ was transferred to another $10 \mathrm{~mL}$ flask, adding $200 \mu \mathrm{L}$ of a 5\% aluminum chloride solution (Synth, Brazil) and completing the volume to nearly $10 \mathrm{~mL}$ with methanol. This flask was shaken and heated to a $20^{\circ} \mathrm{C}$ for $30 \mathrm{~min}$, after which the volume was completed with methanol and the absorbance read at $425 \mathrm{~nm}$ (Spectrophotometer Cary 50, Varian, USA). The concentration of flavonoids was calculated based on a calibration curve using quercetin, Sigma, USA).

\subsection{Statistical Analysis}

Analyzing possible differences between the groups was used analysis of variance (ANOVA) followed by TukeyKramer multiple comparison test (parametric data) and Kruskal-wallis (nonparametric data).

\subsection{Multivariate Statistical Analysis}

In the multivariate statistical analysis all dates are presented in a matrix with the samples as lines (scores) and the columns as the variables (loadings) which in this case were the results of the flavonoid contents and antioxidant activity for each sample. In the principal component analysis (PCA) the PC1 $\times$ PC2 graph of the scores dividing the samples in groups according to their variables (shown in the loadings graph). For this analysis the Pirouette, version 2.6 (Infometrix, Woodinville, WA, EUA) was used.

\section{Results and Discussion}

\subsection{Antioxidant Activity}

The results referring to the antioxidant activity $\left(\mathrm{ED}_{50}\right.$ in $\left.\mu \mathrm{g} / \mathrm{mL}\right)$ of the açaí, cacao, cupuaçú and pitanga samples in water and ethanol are shown in Table 2. These results were obtained using both $\mathrm{DPPH}^{-}$and $\mathrm{ABTS}^{-}$methods by comparison to Vitamin C, a standard antioxidant. In general, the açaí samples and some pitanga samples presented high antioxidant activity, in comparison to vitamin C. However the antioxidant activity may be influenced by the solvent and extraction method used.

The antioxidant activity of cupuaçú pulp (Ccp) and fruit (Cpp) were higher than the commercial pulp of cacao (Ccp) and industrialized Pitanga pulp (Pip) but lower than all the other samples, considering both water and ethanol extracts analyzed by DPPH. The water extracts of pitanga (Eugenia uniflora) analyzed by DPPH, the leaves (Pif) and seeds (Pis) showed similar $\mathrm{ED}_{50}$ results, having the highest activity. Mature pitanga (Pim) and green pitanga fruit (Piv) presented intermediary $\mathrm{ED}_{50}$ results. The industrialized pulp of this fruit (Pip), had a higher $\mathrm{ED}_{50}$, indicating lower antioxidant activity. The samples extracted with ethanol and analyzed $\mathrm{DPPH}$, and the seeds (Pis) presented lower ED50 values, followed by the leaves (Pif), indicating a higher antioxidant activity. Mature pitanga (Pim) presented moderate activity whereas green pitanga fruit (Piv) and industrialized pulp 
Table 2. Antioxidant activity expresses as $\mathrm{ED}_{50}(\mu \mathrm{g} / \mathrm{mL})$ of the açaí, cacau, cupuaçu, and pitanga samples, determined by the DPPH e ABTS ${ }^{-}$methods in comparison with vitamin C.

\begin{tabular}{|c|c|c|c|c|}
\hline \multirow{2}{*}{ Samples } & \multicolumn{2}{|c|}{$\mathrm{DPPH}^{*}$} & \multicolumn{2}{|c|}{ ABTS $^{*}$} \\
\hline & Water & Ethanol & Water & Ethanol \\
\hline & \multicolumn{4}{|c|}{$\mathrm{ED}_{50}$ in $\mu \mathrm{g} / \mathrm{mL}$} \\
\hline Açaí (Açc) & - & - & 17.00 & - \\
\hline Açaí (Açe) & - & - & 67.74 & - \\
\hline Açaí (Açf) & - & - & 16.86 & - \\
\hline Açaí (Açg) & - & - & 17.52 & - \\
\hline Açaí (Açp1) & - & - & 16.99 & - \\
\hline Açaí (Açp2) & - & - & 17.76 & - \\
\hline Cacao fruit (Ccf) & 1580.0 & 7900.0 & 2630.0 & 1880.0 \\
\hline Cacao pulp (Сср) & 6110.0 & 14600 & 5850.0 & 6290.0 \\
\hline Cupuaçú fruit (Cpf) & 2190.0 & 4520.0 & 2590.0 & 3200.0 \\
\hline Cupuaçú pulp (Cpp) & 2320.0 & 7100.0 & 3290.0 & 2410.0 \\
\hline Pitanga green (Piv) & 584.0 & 2354.0 & 428.0 & 1197.0 \\
\hline Pitanga mature (Pim) & 1466.0 & 446.0 & 1258.0 & 2001.0 \\
\hline Pitanga leaves (Pif) & 40.00 & 114.0 & 55.00 & 101.00 \\
\hline Pitanga seeds (Pis) & 41.00 & 32.0 & 53.00 & 67.00 \\
\hline Pitanga industrialized pulp (Pip) & 7626.0 & 9720.0 & 11200 & 8658.0 \\
\hline Vitamin C & 4.00 & 4.00 & 4.00 & 4.00 \\
\hline
\end{tabular}

-: not tested. For abbreviations see Table 1. ${ }^{*}$ Material extracted with water or ethanol.

(Pip) did not present antioxidant activity. In the water extracts, analyzed by ABTS $^{-}$, the leaves (Pif) and seeds (Pis) presented similar results with the highest activity. Green pitanga (Piv), mature pitanga (Pim) and industrialized pulp (Pip), showed a lower antioxidant activity. In the samples extracted with ethanol and ABTS, the seeds (Pis) and leaves (Pif) showed the highest activity, whereas the other samples did not present activity.

The fruit of the açaí palm (Euterpeoleracea) contains anthocyanins, which are natural antioxidants [22]. This was confirmed by the results of the ABTS ${ }^{-}$assay. This high antioxidant activity helps to protect the lipophilic fraction of the fruit.

Both cupuaçú and cacao do not have good antioxidant activity; in the majority of cases, the fresh fruit was slightly superior to the industrialized frozen pulp. Although the sample of cupuaçú presented higher activity than the cacao sample, both were produced by the same manufacturer. The transport conditions may be important factors relating to their quality. With respected to pulps, the amount of the lipid is greater in cupuaçú in comparison to cacao, and in both fruits the amount is always higher than in the pulp. Cupuaçú has a higher concentration of lipids compared to in natura cacao and processed material. This information must be considered when was evaluated the nutritional potential of both analyzed fruits.Cupuaçú has a higher concentration of lipids compared to in natura cacao and processed material. This information must be considered when evaluating the nutritional potential of both analyzed fruits.

Apparently the antioxidant substances present in pitanga are soluble both in water and in ethanol and were extracted in equivalent amounts by both solvents.

\subsection{Amount of Lipids}

Table 3 shows the percentage of lipids, obtained using the Bligh Dyer method, for açaí, cacau and cupuaçú. 
Cupuaçú fruit showed the highest amount of lipids, followed by cacao and açaí. These three typical Brazilian fruits have good percentage of lipids. Cupuaçú for example, is used to prepare exotic candies especially in Northern regions of Brazil. In the case of Cacau and Cupuaçú, the industrialized pulp has lower lipid concentration that the whole fruit, indicating that some of the lipids are lost (or diluted) in processing. These pulps are used to make fruit juice.

\subsection{Flavonoids and Antioxidant Activity}

Polyphenols are secondary metabolites present in foods from plant origin. There are three main types of polyphenols such as, flavonoids, phenolic acids and tannins that are potent antioxidants. These compounds are considered the main substances promoting health benefits as mentioned previously [3] [23].

Table 4 shows the flavonoid content, antioxidant activity and the daily dose of food calculated as necessary to have an antioxidant activity in an adult. For example, people who don't like broccoli or eggplant (daily dose between 20 and 26 g) could eat more chocolate. Oregano and walnuts also present good antioxidant activity, which could please the palate of several people.

Behling et al. [24], reported that the flavonoid content in foods consumed daily is: $44 \mathrm{mg}$ in cereals, $45 \mathrm{mg}$ in grains and nuts, and $126 \mathrm{mg}$ in vegetables and herbs. Most flavonoids come from cacau, coffee, black tea, beer and wine, which generates approximately $420 \mathrm{mg} /$ day, an additional $290 \mathrm{mg} /$ day comes from fruit and juices.

Figure 1 shows the flavonoid contents (mean and standard deviation) each for the fruit and vegetables analyzed. The asterisk marks statistically significant differences between foods. Again, several different types of food present important antioxidant activity, showing that it is not necessary to suffer in order to eat healthily.

Table 3. Percentage of lipids in açaí, cacao, and cupuaçú pulp.

\begin{tabular}{ccc}
\hline Sample & Lipid contents g/3.5g* & Percentage of lipids (\%) \\
\hline Açaí (Aç) & 0.14 & 4.00 \\
Cacao pulp (Ccp) & 0.02 & 0.57 \\
Cacao fruit (Ccf) & 0.58 & 6.82 \\
Cupuaçu pulp (Cpp) & 0.10 & 2.86 \\
Cupuaçu fruit (Cpf) & 1.36 & 38.86 \\
\hline
\end{tabular}

*Sample weight. For abbreviation see Table 1.

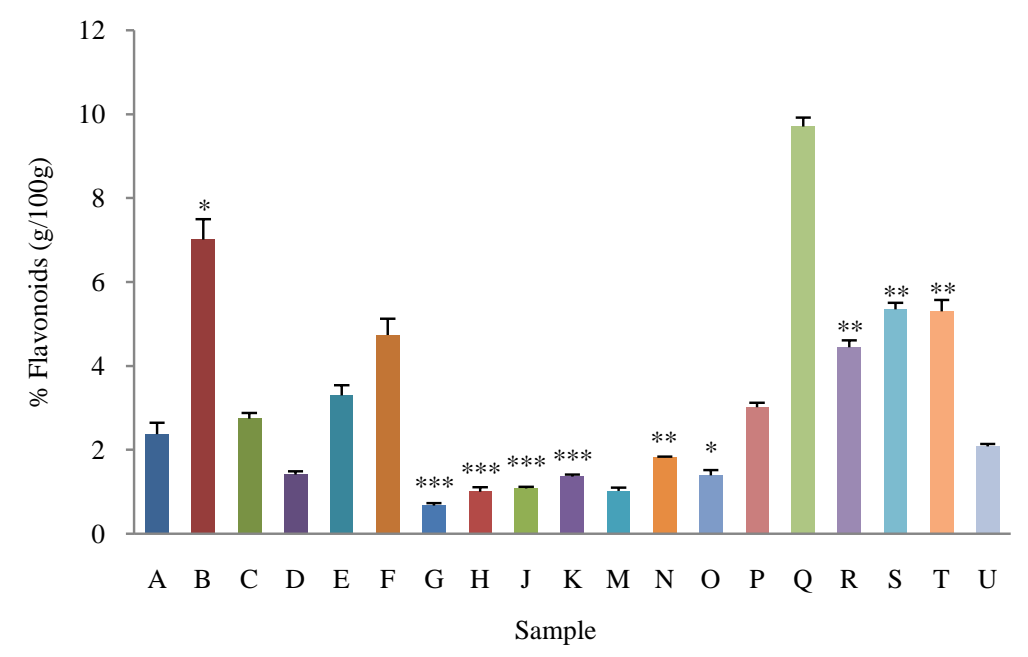

Figure 1. Flavonoids in vegetables and fruit-Mean and Standard Deviation, for each sample, *significant difference $\mathrm{p}<0.05$ (Tukey, T test); **significant difference $\mathrm{p}<0.001$ (Tukey, $\mathrm{T}$ teest); ${ }^{* * *}$ significant difference $\mathrm{p}<$ 0.0001 (Tukey, T test). For abbreviation, see Table 1 . 
Table 4. Flavonoid contents, concentration that reduces the free radicals in $50\left(\mathrm{ED}_{50} \mathrm{in} \mu \mathrm{g} / \mathrm{mL}\right)$ and the necessary daily dose for an antioxidant effect in a $65 \mathrm{~kg}$ individual.

\begin{tabular}{|c|c|c|c|c|c|c|}
\hline & \multicolumn{4}{|c|}{ Flavonoids (g/100g) } & \multirow{2}{*}{$\begin{array}{c}\mathrm{DPPH}^{\mathrm{a}} \\
\left(\mathrm{ED}_{50} \mu \mathrm{g} / \mathrm{mL}\right)\end{array}$} & \multirow{2}{*}{$\begin{array}{c}\text { Daily } \\
\text { dose (g) }\end{array}$} \\
\hline & Average & $\mathrm{DP}$ & $\mathrm{CV} \%{ }^{\mathrm{b}}$ & uncertainty $^{\mathrm{c}}$ & & \\
\hline Bitter chocolate (N) & 1.83 & 0.01 & 0.77 & 0.31 & 89.50 & 8.0 \\
\hline Cooked broccoli (H) & 1.01 & 0.10 & 9.59 & 3.91 & 224.66 & 20.0 \\
\hline Cooked eggplant peel (D) & 1.41 & 0.08 & 5.37 & 2.19 & 69.88 & 6.0 \\
\hline Cooked eggplant pulp (F) & 4.74 & 0.39 & 8.20 & 3.35 & 284.33 & 26.0 \\
\hline Cooked soybean $(\mathbf{U})$ & 2.09 & 0.05 & 2.30 & 0.94 & 156.96 & 14.0 \\
\hline Cooked squash (B) & 7.01 & 0.49 & 6.93 & 2.83 & 564.68 & 53.0 \\
\hline Cooked tomato $(\mathbf{T})$ & 5.30 & 0.28 & 5.27 & 2.15 & 115.25 & 10.0 \\
\hline Diet chocolate (M) & 1.03 & 0.07 & 6.61 & 2.70 & 530.45 & 48.0 \\
\hline Kale (O) & 1.39 & 0.13 & 9.19 & 3.75 & 221.09 & 20.0 \\
\hline Milk chocolate $(\mathbf{J})$ & 1.08 & 0.04 & 3.32 & 1.36 & 151.90 & 14.0 \\
\hline Oregano $(\mathbf{P})$ & 3.02 & 0.11 & 3.50 & 1.43 & 85.87 & 8.0 \\
\hline Parsley (R) & 4.45 & 0.16 & 3.66 & 1.50 & 132.10 & 12.0 \\
\hline Raw broccoli (G) & 0.68 & 0.05 & 7.32 & 2.99 & 229.14 & 21.0 \\
\hline Raw eggplant peel (C) & 2.75 & 0.13 & 4.67 & 1.91 & 171.21 & 15.0 \\
\hline Raw eggplant pulp (E) & 3.30 & 0.24 & 7.35 & 3.00 & 104.95 & 9.0 \\
\hline Raw squash (A) & 2.38 & 0.27 & 11.53 & 4.71 & 390.72 & 35.0 \\
\hline Raw tomato (S) & 5.35 & 0.16 & 2.98 & 1.22 & 147.37 & 13.0 \\
\hline Walnuts $(\mathbf{Q})$ & 9.71 & 0.21 & 2.19 & 0.89 & 93.11 & 8.0 \\
\hline White chocolate (K) & 1.37 & 0.04 & 2.65 & 1.08 & 255.75 & 23.0 \\
\hline
\end{tabular}

Letter in parenthesis was used in chemometric analysis (PCA). For abbreviation, see Table 1. ${ }^{\mathrm{a}}$ ED50 is the concentration that eliminates $50 \%$ of free

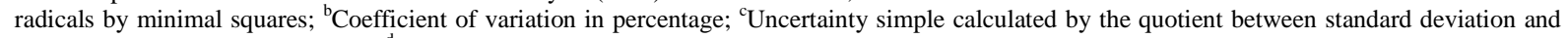
square root of number of measures; ${ }^{\mathrm{d}}$ Daily dose calculated in grams for a person of 65 kilogram to obtain the antioxidant effect.

\subsection{Principal Component Analysis}

Principal components analysis of the results described in Table 4, is shown in Figure 2(a) (Scores) and Figure 2(b) (Loadings).

Multivariate statistical analysis is shown in Figure 2. The loadings are shown in Figure 2(b). Flavonoids are found in the upper left and antioxidant activity $\left(\mathrm{ED}_{50}, \mu \mathrm{g} / \mathrm{mL}, \mathrm{DPPH}\right)$ in the lower right corner. The higher content of flavonoids promotes good antioxidant activity (lower $\mathrm{ED}_{50}$ value). Figure 2(a) must be analyzed together with Figure 2(b), which shows the Scores, representing food samples. Most samples are placed in the center of the graph: for amounts of flavonoids between 0.68 to $5.36 \mathrm{~g} / 100 \mathrm{~g}$ the antioxidant activity ranged from 69.88 to $530.45 \mu \mathrm{g} / \mathrm{g}$, indicating that there is a linear correlation between flavonoid content and antioxidant activity, as mentioned earlier in this paper; except for the samples of cooked squash and walnuts, the first with a good content of flavonoids and low antioxidant activity and the second, with good content and good flavonoid antioxidant activity. These results suggest that flavonoids present in walnuts are responsible for the antioxidant activity but in cooked squash other substances are probably involved in this activity.

Free radicals are produced more rapidly and abundantly in old people, in both young and elderly people, the consumption of food and drinks increase the appearance of many diseases such as obesity, cardiovascular disorders, diabetes and cancer [3]. Many food shave been recognized as beneficial to health because they have antioxidant characteristics and break the oxidative chain, decreasing the concentration of free radicals in organisms [9]. 


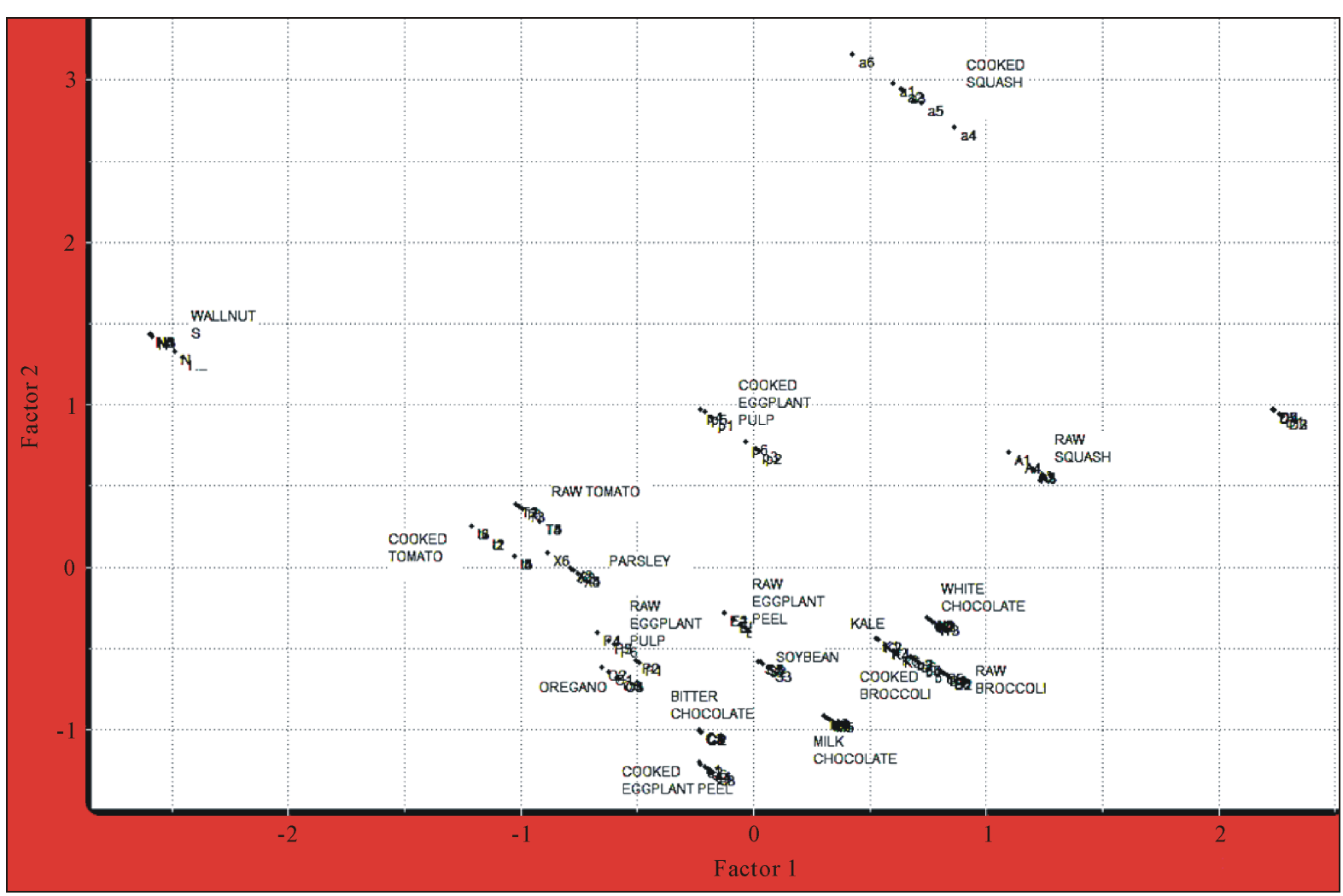

(a)

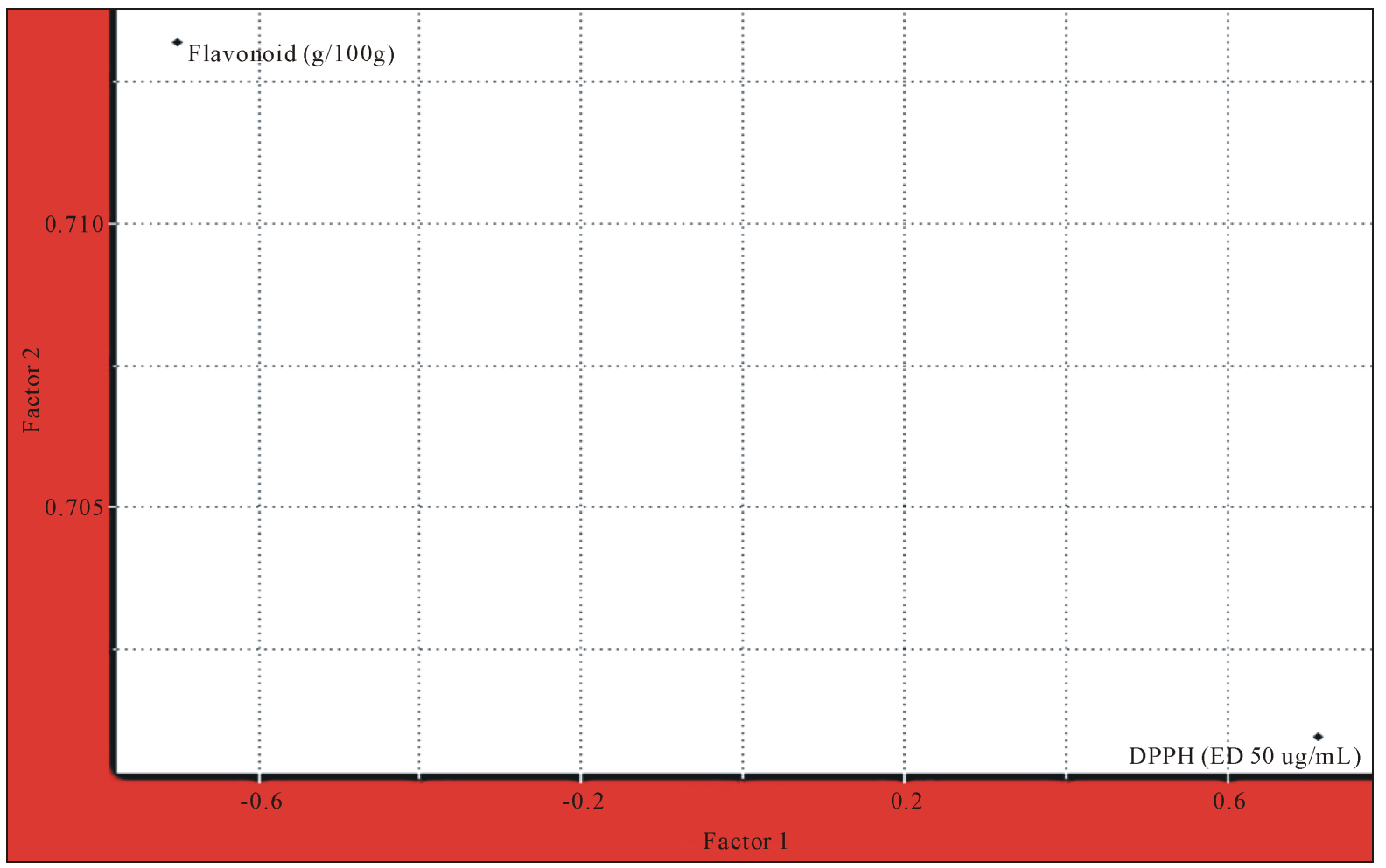

(b)

Figure 2. Principal component analysis ((a) Scores, and (b) Loadings). Loadings represent analyzes (flavonoid content and antioxidant activity) and Scores food samples and their treatment. For description of samples, see Table 1. 
Based on these results, it was defined that samples with $\mathrm{ED}_{50}$ up to $500 \mu \mathrm{g} / \mathrm{mL}$ show antioxidant activity, but higher values are not indicative of this activity. Thus, most of the food samples analyzed showed antioxidant activity, especially bitter chocolate, baked eggplant peel, oregano and walnuts. Azevedo and Rodriguez-Amaya [25] reported that the squash is rich in carotenoids which have antioxidant action. Miean and Mohamed [26] demonstrated that broccoli has a high amount of quercetin, with important antioxidant activity. Chocolate contains catechins and epicatechins, a type of flavonoid which confers antioxidant activity to bitter chocolate [27]. Parsley contains apigenin, a flavonoid with antioxidant activity [28].

Flavonoids are the main class of chemical compounds found in with antioxidant activity [9]. Most of the food samples showed presented flavonoids in their composition. The analysis of total flavonoids suffer influences of many factors, including handling, storage, preparation, processing, climate and season [29].

\section{Conclusion}

The present study analyzed the antioxidant properties and chemical composition of diverse foods, cupuaçú fruit showed the highest amount of lipids, followed by cacao and açaí. According to the results, some types of food presented important antioxidant activity and flavonoid content, justifying the importance of their presence in human diet, aiding in the reduction of free radicals and reducing the related diseases. However, not enough is known about the biodisponibility of flavonoids and their chronic ingestion. Further studies on the biodisponibility and mechanisms of action will be necessary, as well as their antioxidant activity and possible synergy with other dietary components.

\section{Acknowledgements}

ACHFS would like to thank CAPES and FAPESP for post-doctoral fellowships.

\section{References}

[1] Dixit, S. and Ali, H. (2010) Antioxidant Potential Some Medicinal Plants of Central India. Journal of Cancer Therapy, 1, 87-90. http://dx.doi.org/10.4236/jct.2010.12014

[2] Galvão, E.L., Da Silva, D.C.F., Moreira, A.V.B., et al. (2008) Avaliação do potencial antioxidante e extração subcrítica do óleo de linhaça. Food Science and Technology, 28, 551-557. http://dx.doi.org/10.1590/S0101-20612008000300008

[3] Han, X., Shen, T. and Lou, H. (2007) Dietary Polyphenols and Their Biological Significance. International Journal Molecular Science, 8, 950-988. http://dx.doi.org/10.3390/i8090950

[4] Segev, A., Badani, H., Kapulnik, K., Shomer, I., Oren-Shamir, M. and Galili, S. (2010) Determination of Polyphenols, Flavonoids and Antioxidant Capacity in Colored Chick-Pea (Cicer arietinum L.). Journal Food Science, 75, S115S119. http://dx.doi.org/10.1111/j.1750-3841.2009.01477.x

[5] Davies, K.J. (2000) Oxidative Stress, Antioxidant Defenses, and Damage Removal, Repair, and Replacement Systems. IUBMB Life, 50, 279-289. http://dx.doi.org/10.1080/15216540051081010

[6] Shahidi, F., Janitha, P.K. and Wanasundara, P.D. (1992) Phenolic Antioxidants. Critical Review of Food Science and Nutrition, 202, 307-324. http://dx.doi.org/10.1080/10408399209527581

[7] Fremont, L., Gozzelino, M.T., Franchi, M.P. and Linard, A. (1998) Dietary Flavonoids Reduce Lipid Peroxidation in Rats Fed Polyunsaturated and Monounsaturated Fat Diets. Journal of Nutrition, 128, 1495-1502.

[8] Lobo, V., Patil, A., Phatak, A. and Chandra, N. (2010) Free Radicals, Antioxidants and Functional Foods: Impact on Human Health. Pharmacognosy Review, 4, 118-126. http://dx.doi.org/10.4103/0973-7847.70902

[9] Scalbert, A., Manach, C. and Morand, C. (2005) Dietary Polyphenols and the Prevention of Diseases. Critical Reviews in Food Science and Nutrition, 45, 287-306. http://dx.doi.org/10.1080/1040869059096

[10] Xu, B.J., Yuan, S.H. and Chang, S.K.C. (2007) Comparative Analyses of Phenolic Composition, Antioxidant Capacity and Color of Cool Season Legumes and Other Selected Food Legumes. Journal of Food Science, 72, S167-S177. http://dx.doi.org/10.1111/j.1750-3841.2006.00261.x

[11] Geil, P.B. and Anderson, J.W. (1994) Nutrition and Health Implications of Dry Beans: A Review. Journal of the American College of Nutrition, 13, 549-558. http://dx.doi.org/10.1080/07315724.1994.10718446

[12] Heimler, D., Vignolini, P., Dini, M.G. and Romani, A. (2005) Rapid Tests to Assess the Antioxidant Activity of Phaseolus vulgaris L. Dry Beans. Journal of Agricultural and Food Chemistry, 53, 3053-3056.

http://dx.doi.org/10.1021/jf049001r 
[13] Cardador-Martinez, A., Loacra-Piña, G. and Oomah, B.D. (2002) Antioxidant Activity in Common Beans (Phaseolus vulgaris L.). Journal of Agricultural and Food Chemistry, 50, 6975-6980. http://dx.doi.org/10.1021/jf020296n

[14] Azevedo, L., Gomes, J.C., Stringheta, P.C., Gontijo, A.M.M.C., Padovani, C.R., Ribeiro, L.R. and Salvadori, D.M.F. (2003) Black Bean (Phaseolus vulgaris L.) as Protective Agent against DNA Damage in Mice. Food and Chemical Toxicology, 41, 1671-1676. http://dx.doi.org/10.1016/S0278-6915(03)00173-X

[15] Cardador-Martínez, A., Albores, A., Bah, M., Calderón-Salinas, V., Castaño-Tostado, E., Guevara-González, R., Shimada-Miyasaka, A. and Loarca-Piña, G. (2006) Relationship among Antimutagenic Antioxidant and Enzymatic Activities of Methanolic Extract from Common Beans (Phaseolus vulgaris L.). Plant Foods for Human Nutrition, 61, 161168. http://dx.doi.org/10.1007/s11130-006-0026-4

[16] Mejía, E.G., Castaño-Tostado, E. and Loarca-Piña, G. (1999) Antimutagenic Effects of Natural Phenolic Compounds in Beans. Mutation Research-Genetic Toxicology and Environmental Mutagenesis, 441, 1-9. http://dx.doi.org/10.1016/S1383-5718(99)00040-6

[17] Dong, M., He, X. and Liu, R.H. (2007) Phytochemicals of Black Bean Seed Coats: Isolation, Structure Elucidation and Their Antiproliferative and Antioxidative Activities. Journal of Agricultural and Food Chemistry, 55, 6044-6051. http://dx.doi.org/10.1021/jf070706d

[18] Aparicio-Fernández, X., Reynoso-Camacho, R., Castaño-Tostado, E., García-Gasca, T., González de Mejía, E., GuzmánMaldonado, S., Elizondo, G., Yousef, G.G., Lila M.A. and Loarca-Piña, G. (2008) Antiradical Capacity and Induction of Apoptosis in HeLa Cells by a Phaseolus vulgaris Extract. Plant Foods for Human Nutrition, 63, 35-40. http://dx.doi.org/10.1007/s11130-007-0066-4

[19] Banskota, A.H., Tezuka, Y., Adnyana, I.K., Midorikawa, K., Matsushige, K., Message, D., Huertas, A.A.G. and Kadota, S. (2000) Cytotoxic, Hepatoprotective and Free Radical Scavenging Effects of Propolis from Brazil, Peru, the Netherlands and China. Journal of Ethnopharmacology, 72, 239-246. http://dx.doi.org/10.1016/S0378-8741(00)00252-X

[20] Pellegrini, N., Proteggente, A., Pannala, A., Yang, M. and Rice-Evans, C. (1999) Antioxidant Activity Applying an Improved ABTS Radical Cation Decolorization Assay. Free Radicals in Biological Medicine, 26, 1231-1237. http://dx.doi.org/10.1016/S0891-5849(98)00315-3

[21] Bligh, E.G. and Dyer, W.J. (1959) A Rapid Method of Total Lipid Extraction and Purification. Canadian Journal of Biochemistry and Physiology, 37, 911-917. http://dx.doi.org/10.1139/059-099

[22] Menezes, E.M.S., Torres, A.L. and Srur, A.U.S. (2008) Valor nutricional da polpa de açaí (Euterpe oleracea Mart.) liofilizada. Acta Amazonica, 38, 311-316. (In Portuguese) http://dx.doi.org/10.1590/S0044-59672008000200014

[23] Brend, Y., Galili, L., Badani, H., Hovav, R. and Galili, S. (2012) Total Phenolic Content and Antioxidant Activity of Red and Yellow Quinoa (Chenopodium quinoa Willd.) Seeds as Affected by Baking and Cooking Conditions. Food and Nutrition Sciences, 3, 1150-1155. http://dx.doi.org/10.4236/fns.2012.38151

[24] Behling, E.B., Sendão, M.C., Francescato, H.D.C., Antunes, L.M.G. and Bianchi, M.L.P. (2004) Flavonóide quercetina: Aspectos gerais e ações biológicas. Alimentos e Nutrição, 15, 285-292. (In Portuguese)

[25] Azevedo-Meleiro, C.H. and Rodriguez-Amaya, D.B. (2007) Qualitative and Quantitative Differences in Carotenoid Composition among Cucurbita moschata, Cucurbita maxima, and Cucurbita pepo. Journal of Agricultural and Food Chemistry, 55, 4027-4033. http://dx.doi.org/10.1021/jf063413d

[26] Miean, K.H. and Mohamed, S. (2001) Flavonoid (Myricetin, Quercetin, Kaempferol, Luteolin, and Apigenin) Content of Edible Tropical Plants. Journal of Agricultural and Food Chemistry, 49, 3106-3112.

[27] Arts, I.C.W., Hollman, P.C.H. and Kromhout, D. (1999) Chocolate as a Source of Tea Flavonoids. The Lancet, 354, 488. http://dx.doi.org/10.1016/S0140-6736(99)02267-9

[28] Luthria, D.L. (2008) Influence of Experimental Conditions on the Extraction of Phenolic Compounds from Parsley (Petroselinum crispum) Flakes Using a Pressurized Liquid Extractor. Food Chemistry, 107, 745-752. http://dx.doi.org/10.1016/j.foodchem.2007.08.074

[29] Piccaglia, R., Marotti, M., Chiavari, G. and Nandini, N. (1997) Effects of Harvesting Date and Climate on the Flavonoid and Carotenoid Contents of Marigold (Calendula officinalis L.). Flavour and Fragrance Journal, 12, 85-90. http://dx.doi.org/10.1002/(SICI)1099-1026(199703)12:2<85::AID-FFJ616>3.0.CO;2-L 